\title{
Vulnerability of Ground Water to Contamination, Northern Bexar County, Texas
}

Water-Resources Investigations Report 03-4072 
U.S. Department of the Interior

U.S. Geological Survey

\section{Vulnerability of Ground Water to Contamination, Northern Bexar County, Texas}

By Amy R. Clark

\section{U.S. GEOLOGICAL SURVEY}

Water-Resources Investigations Report 03-4072

In cooperation with the San Antonio Water System

Austin, Texas

2003 


\section{U.S. DEPARTMENT OF THE INTERIOR}

Gale A. Norton, Secretary

\section{U.S. GEOLOGICAL SURVEY}

Charles G. Groat, Director

Any use of trade, product, or firm names is for descriptive purposes only and does not imply endorsement by the U.S. Government.

For additional information write to

\section{District Chief}

U.S. Geological Survey

8027 Exchange Dr.

Austin, TX 78754-4733

E-mail: dc_tx@usgs.gov

Copies of this report can be purchased from

U.S. Geological Survey

Information Services

Box 25286

Denver, CO 80225-0286

E-mail: infoservices@usgs.gov 


\section{CONTENTS}

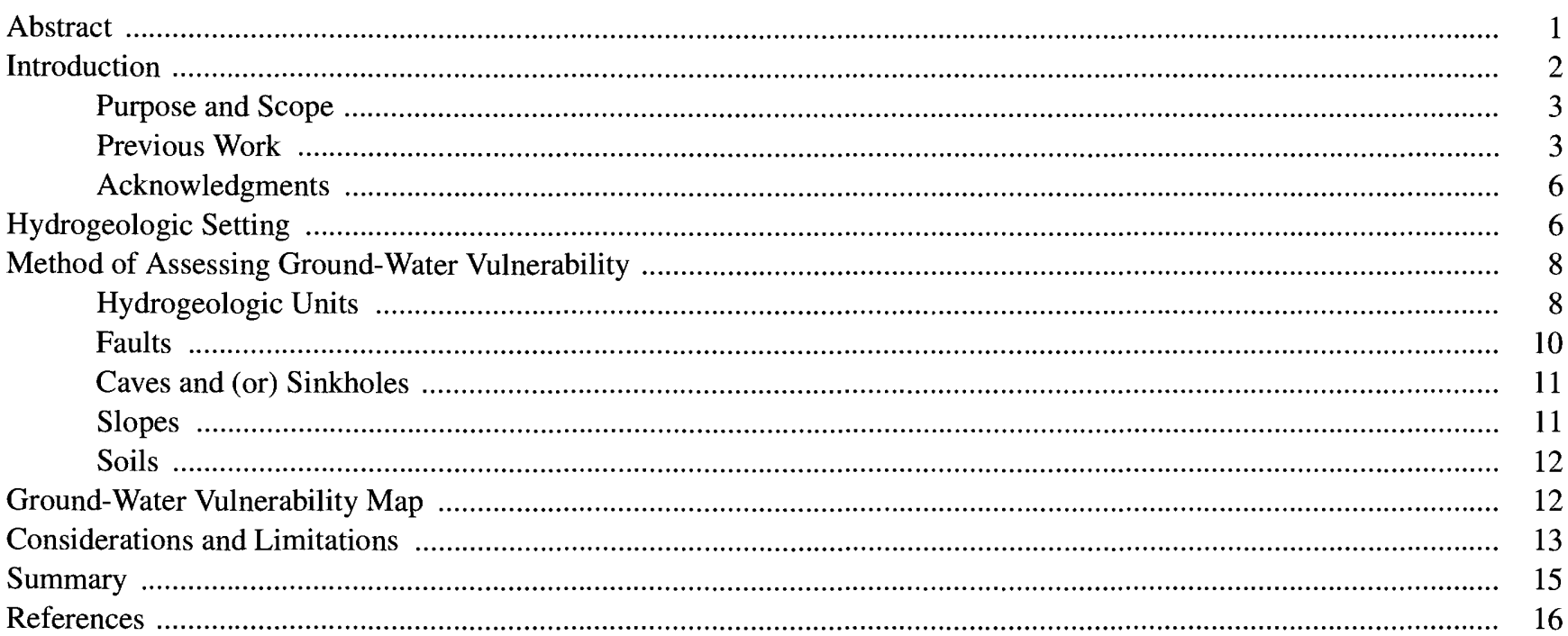

\section{PLATE}

[Plate is in pocket]

1. Map showing vulnerability of ground water to contamination, northern Bexar County, Texas

\section{FIGURES}

1. Map showing locations of study area and Balcones fault zone ................................................................ 2

2. Generalized section summarizing the hydrogeologic framework of south-central Texas .................................. 4

3. Diagram showing an example of how vulnerability ratings for the hydrogeologic units and other natural features relate to composite ratings

4. Diagram showing cumulative relative frequency of composite vulnerability ratings computed for selected categories of natural features and for the entire study area

\section{TABLES}

1. Summary of the geologic characteristics and hydrologic properties of the hydrogeologic units that crop out in the study area of northern Bexar County, Texas

2. Composite vulnerability ratings for the hydrogeologic units and other natural features in the study area of northern Bexar County, Texas 


\title{
Vulnerability of Ground Water to Contamination, Northern Bexar County, Texas
}

\author{
By Amy R. Clark
}

\section{Abstract}

The Trinity aquifer, composed of Lower Cretaceous carbonate rocks, largely controls the ground-water hydrology in the study area of northern Bexar County, Texas. Discharge from the Trinity aquifer recharges the downgradient, hydraulically connected Edwards aquifer-one of the most permeable and productive aquifers in the Nation and the sole source of water for more than a million people in south-central Texas. The unconfined, karstic outcrop of the Edwards aquifer makes it particularly vulnerable to contamination resulting from urbanization that is spreading rapidly northward across an "environmentally sensitive" recharge zone of the Edwards aquifer and its upgradient "catchment area," composed mostly of the less permeable Trinity aquifer.

A better understanding of the Trinity aquifer is needed to evaluate water-management decisions affecting the quality of water in both the Trinity and Edwards aquifers. A study was made, therefore, in cooperation with the San Antonio Water System to assess northern Bexar County's vulnerability to ground-water contamination. The vulnerability of ground water to contamination in this area varies with the effects of five categories of natural features (hydrogeologic units, faults, caves and (or) sinkholes, slopes, and soils) that occur on the outcrop and in the shallow subcrop of the Glen Rose Limestone.

Where faults affect the rates of recharge or discharge or the patterns of ground-water flow in the Glen Rose Limestone, they likewise affect the risk of water-quality degradation. Caves and sinkholes generally increase the vulnerability of ground water to contamination, especially where their occurrences are concentrated. The slope of land surface can affect the vulnerability of ground water by controlling where and how long a potential contaminant remains on the surface. Disregarding the exception of steep slopes-which are assumed to have no soil cover - the greater the slope, the less the risk of ground-water contamination. Because most soils in the study area are uniformly thin, they have only minimal effect on the vulnerability of ground water to contamination.

The results of hydrogeologic mapping during the present study divide the outcrop of the Glen Rose Limestone into five mappable intervals, labeled (youngest to oldest) A through E. Of these intervals, only the middle (C) and the lowermost $(\mathrm{E})$ generally provide appreciable permeability.

The vulnerability assessment provided herein was determined by combining the presumed effects of selected natural features (with individual vulnerability ratings ranging from 0 through 35 ) using a grid-based, multilayer system of digital datasets and geographic information system analysis. The resulting vulnerability map comprises composite vulnerability ratings that range from 26 through 104. The relatively less vulnerable areasthose containing no faults, sinkholes, or cavesoccupy about 92 percent of the study area. The most vulnerable areas are those containing both a fault and one or more caves. The distribution of the most vulnerable areas-which trend from southwest to northeast, roughly parallel to the Balcones fault zone-occur mainly where faults intersect caves. 


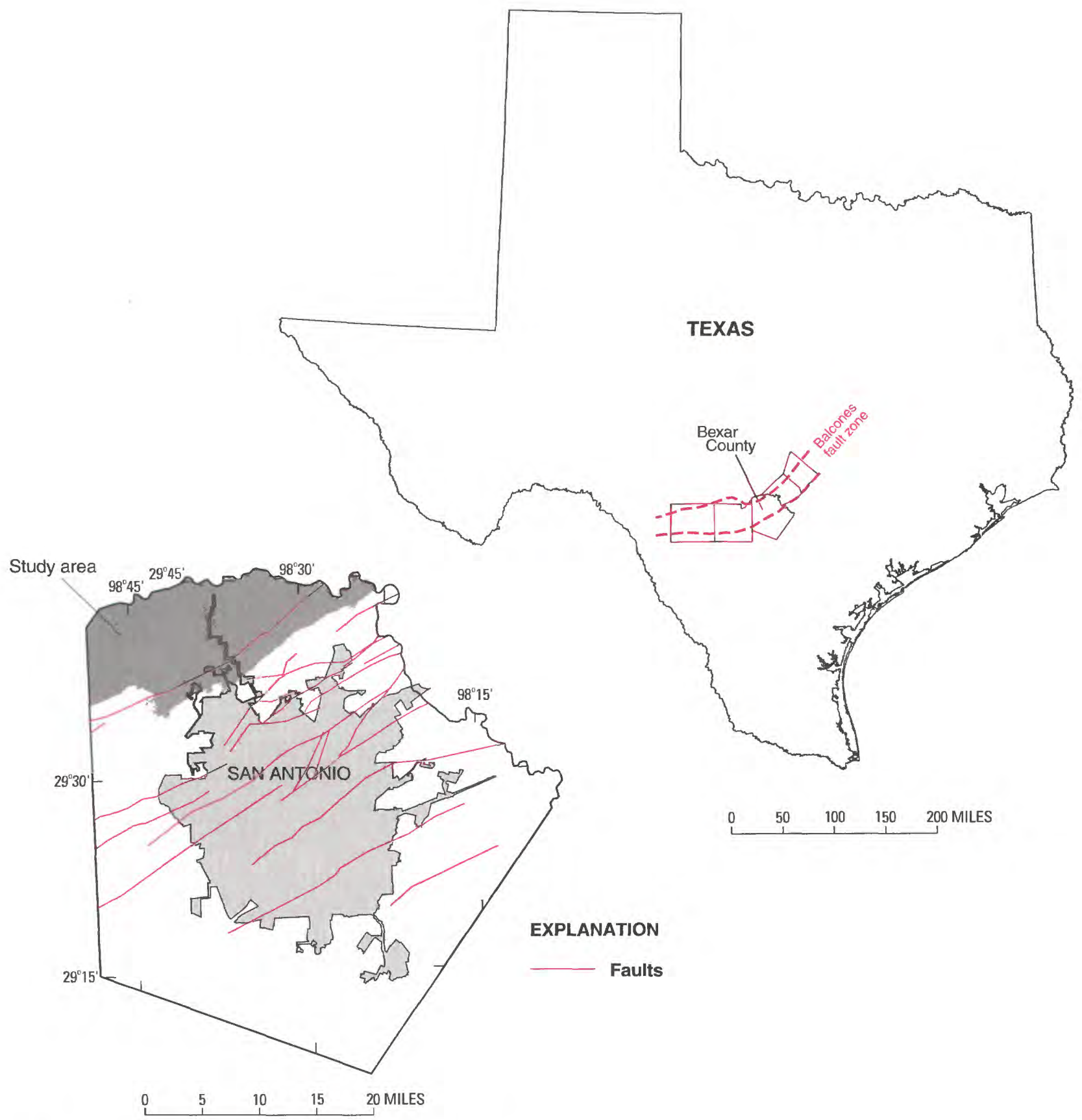

Figure 1. Locations of study area and Balcones fault zone.

No part of the vulnerability assessment offered herein should preclude or minimize the importance of detailed, on-site inspections by qualified hydrogeologists. The evolving understanding of the vulnerability of ground water to contamination in northern Bexar County will improve as additional data are collected and analyzed.

\section{INTRODUCTION}

The ground-water hydrology of the study area in northern Bexar County, Texas (fig. 1), is controlled largely by the Trinity aquifer, a subsurface reservoir composed of relatively flat-lying carbonate strata of Early Cretaceous age. Discharge from the Trinity aquifer recharges the downgradient Edwards aquifer-a 
steeply dipping, extensively faulted, and locally karstic sequence of mostly dolostone and limestone. One of the most permeable and productive aquifers in the Nation (providing large quantities of water to agricultural, industrial, and recreational interests in south-central Texas), the Edwards aquifer is the sole-source water supply for more than a million people in the greater San Antonio area of central Bexar County. The U.S. Environmental Protection Agency designation of the Edwards aquifer as a sole-source aquifer (van der Leeden and others, 1990) officially confirms that contamination of this aquifer would threaten the health and well being of residents, business and industry, as well as the environment of Bexar County.

The population of Bexar County has increased an average of nearly 20 percent per decade since 1960 , amounting to more than a 100-percent increase through 2000 (U.S. Census Bureau, 2002). The majority of Bexar County's nearly 1.5 million population resides in San Antonio, one of the 10 largest cities in the United States. Most of the population growth and associated urban sprawl (urbanization) is occurring northward across an "environmentally sensitive" outcrop, or recharge zone, of the Edwards aquifer and into the "catchment area" of runoff from the comparatively less permeable Trinity aquifer (fig. 2). The karstic nature of the Edwards aquifer makes it particularly vulnerable to contamination associated with the rapidly increasing urbanization atop not only its recharge zone but also its upgradient catchment area.

The vulnerability of ground water to contamination in the study area depends on the distribution and characteristics of hydrogeologic units; the presence or absence of faults, caves, and sinkholes; and on the specific slopes and soils on the surface and (or) in the shallow subcrop of the Trinity aquifer. Because the individual effects of these conditions vary spatially, the composite (net) vulnerability varies accordingly.

The outcrop of the Trinity aquifer in northern Bexar County consists of the upper member and the uppermost part of the lower member of the Glen Rose Limestone (table 1). Because most water that recharges the Edwards aquifer must first discharge from the upgradient Trinity aquifer, the contamination of ground water in the Glen Rose Limestone affects the potential for contamination of the Edwards aquifer.

Relatively impervious streambeds of Glen Rose Limestone that drain toward the pervious recharge zone of the highly permeable Edwards aquifer make the Edwards aquifer highly susceptible to contamination originating atop the Trinity aquifer. That susceptibility and a growing dependence on the Edwards aquifer make the quality of water that recharges this aquifer a critical concern for public officials who are expected to make informed, scientifically defensible water-management decisions regarding the future of this water resource (Focazio and others, 2002). A better understanding of the vulnerability of the Trinity aquifer to contamination in northern Bexar County is prerequisite to adequate evaluation of alternative water-management decisions affecting the quality of water in the downgradient Edwards aquifer.

\section{Purpose and Scope}

The present study was undertaken by the U.S. Geological Survey in cooperation with the San Antonio Water System to quantify and describe the vulnerability of ground water to contamination in the study area (180 square miles) of northern Bexar County. "Vulnerability to contamination," as applied herein depends on the distribution and characteristics of the hydrogeologic units and other (selected) natural features of the local environment - all of which are intrinsic, or independent of human activity (National Research Council, 1993, p. 17). These characteristics include the: (1) relative permeability of the outcropping hydrogeologic units (composed predominantly of Glen Rose Limestone); (2) presence or absence of faults, caves, and sinkholes; and (3) influence of land-surface slope and soil type. In addition to summarizing the distribution and characteristics of the hydrogeologic units and other natural features in the study area, this report presents a map and an explanation of the area's vulnerability to groundwater contamination.

\section{Previous Work}

Much of the background information and methodology used for the present study results from work by Stein and Ozuna (1995) and A.K. Clark (2000, 2003). Interested readers are referred to the first two of these reports for explanations of the geologic framework, hydrogeologic characteristics, and ground-water vulnerability of the Edwards aquifer recharge zone in northern Bexar County.

Clark's (2000) use of five categories of natural features to assess the vulnerability of the Edwards aquifer-on the basis of rating systems developed by Aller and others (1987) and the Texas Natural Resource Conservation Commission (1995) - was adapted for the 


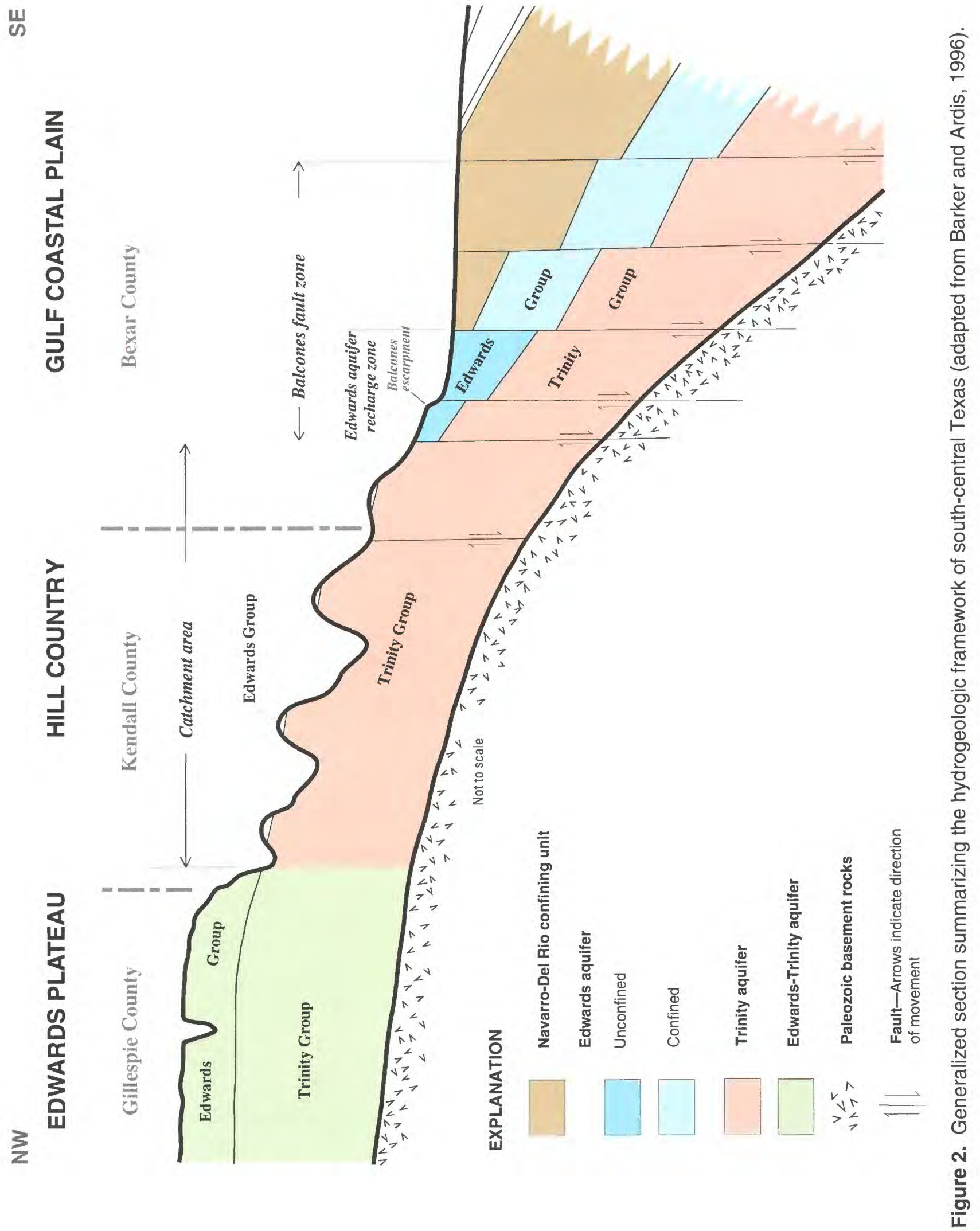


Table 1. Summary of the geologic characteristics and hydrologic properties of the hydrogeologic units that crop out in the study area of northern Bexar County, Texas

[Groups, formations, and members modified from Rose (1972), Ashworth (1983), Barker and Ardis (1996); lithology modified from Dunham (1962); field identification and cave development adapted from A.K. Clark (2003); and porosity type modified from Choquette and Pray (1970). AQ, aquifer; CU, confining unit]

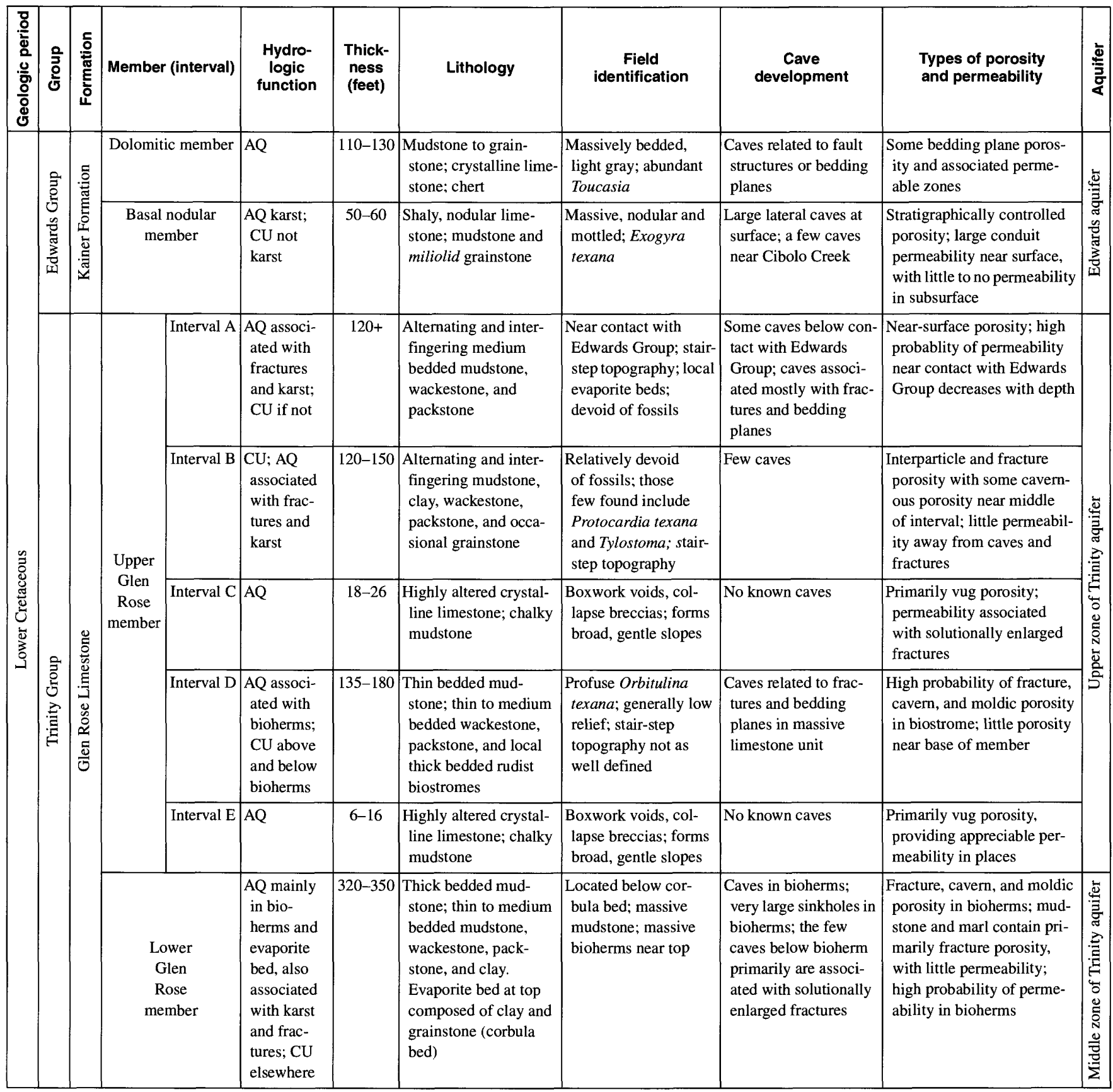

present study. The northern limit of the vulnerability map resulting from Clark's (2000, pl. 1) earlier work (pertaining to the Edwards aquifer) abuts the southern limit of the vulnerability map presented herein (Trinity aquifer).
Clark (2003) describes the results of a study at the Camp Bullis Training Site (U.S. Army) in northern Bexar County with the purpose of better understanding the conditions of recharge to the Glen Rose Limestone 
at that site and the consequential potential for contamination of the downgradient Edwards aquifer.

\section{Acknowledgments}

The author wishes to thank Brian Murphy and Chris Beal (Camp Stanley, U.S. Army), Dusty Bruns and Jerry Thomson (Camp Bullis, U.S. Army), and Deirdre Hisler (Government Canyon State Natural Area) for their valuable assistance during this study. Thanks are extended to Dr. George Veni (George Veni \& Associates) and the Texas Speleological Survey for their assistance with the provisional release of cave locations and for aiding in the assessment of cave zones. Thanks also are owed to David Amsbury and William Ward (University of Texas-San Antonio), Alvin Shultz (independent consultant), and William Feathergail Wilson (Strata Geological Services, Inc.).

The author appreciates special contributions of U.S. Geological Survey colleagues, notably those of Diana Pedraza (for her considerable help with report preparation) and Allan Clark and Ted Small (retired) for their guidance and generous sharing of geologic expertise. The author also wishes to acknowledge the considerable benefit afforded by all the property owners who granted access to their property.

\section{HYDROGEOLOGIC SETTING}

The hydrogeologic framework of south-central Texas comprises (from northwest to southeast) the Edwards Plateau, Hill Country, and Gulf Coastal Plain (fig. 2). The Edwards Plateau is an upland region of thin, rocky soils that veneer an expansive mass of layered, relatively flat-lying sedimentary rocks. The Hill Country is a comparatively rugged, scenic region punctuated by a dendritic drainage system of deeply entrenched, steep-sided canyons that contain spring-fed streams, many of which originate near the southeastern margin of the Edwards Plateau. The Gulf Coastal Plain consists of a rolling to virtually flat prairie land atop a gulfward-thickening, sharply dipping wedge of mostly fine-grained sediments that confine the underlying Edwards aquifer.

The Balcones fault zone is a southwest-tonortheast trending system of mostly high-angle, downto-the-gulf, en echelon faults along the northwestern margin of the Gulf Coastal Plain. These faults profoundly affect flow patterns in the Edwards aquifer, one of the most productive subsurface reservoirs of potable water in the world. The Balcones escarpment, which separates the Hill Country from the Gulf Coastal Plain, is characterized by a prominent break-in-relief along the updip edge of the Balcones fault zone.

Removed by erosion from most of the study area as well as from the rest of the Hill Country, the Edwards Group comprises the Edwards aquifer in the Balcones fault zone. In the study area as well as throughout the rest of the Hill Country, erosional remnants of the Edwards Group cap many of the highest hills that are otherwise composed of Glen Rose Limestone of the Trinity Group. The Kainer Formation of the Edwards Group, which in the study area consists only of its basal nodular and dolomitic members (table 1), is formed mostly of nodular limestone, dolomitic limestone, and mudstone. As the result of downfaulting in the Balcones fault zone, the younger Kainer Formation is juxtaposed alongside the older Glen Rose Limestone near the southern boundary of the study area (fig. 1).

The Glen Rose Limestone, which crops out over about 90 percent of the study area, is composed of (informal) lower and upper members. Whereas the upper member is characteristically thin-bedded and composed mostly of alternating beds of limestone and marl, the lower member of the Glen Rose Limestone typically is composed of relatively massive, fossiliferous limestone. The "stair-step," terraced-hill topography that dominates the Hill Country results largely from contrasting rates of erosion between the beds of relatively resistant limestone and comparatively soft marl in the upper Glen Rose. The Glen Rose Limestone is uncharacteristically permeable in its outcrop and shallow subsurface of northern Bexar County (Veni, 1994), where caves and (or) sinkholes (surface expressions of structural collapse above a solutional cavity) have developed in elevated areas north of the Balcones escarpment.

Composed of faulted, fractured, and locally karstic carbonate rocks, the highly permeable Edwards aquifer is recharged primarily by runoff from drainage basins extending across the Hill Country from the Edwards Plateau. Known locally as the "catchment area" for the Edwards aquifer, these basins receive precipitation that averages about 29 inches per year over the Hill Country (Owenby and Ezell, 1992; Lanning-Rush, 2000). Much of the infiltrated precipitation discharges from upper parts of the Trinity aquifer as springflow or base flow into streams that convey this water to the outcrop (recharge zone) of the downgradient Edwards aquifer. Streams draining the catchment area flow generally southward atop the relatively 
impervious Glen Rose Limestone and lose all their base flow and most of their flood flow when and where they reach the pervious outcrop of the Edwards aquifer. Water entering the Edwards aquifer in Bexar County flows mostly southward to points of discharge (mainly municipal wells) and then northeastward-parallel or nearly parallel to faults composing the northeasttrending Balcones fault zone-into Comal and Hays Counties, where most of the remaining water discharges through Comal and San Marcos Springs.

The Trinity aquifer is composed of three wateryielding zones, the upper two of which (table 1) crop out in the study area. The upper zone is composed of the upper member of the Glen Rose Limestone and the uppermost part of the middle zone is composed of the lower member of the Glen Rose Limestone. The downward movement of water typically is impeded by highly indurated, predominantly mudstone interbeds that are interspersed throughout the Glen Rose Limestone but are most common in the upper member of this formation (Barker and Ardis, 1996). Ground water flows laterally atop these hydraulically tight mudstones more readily than it flows vertically. Consequently, much of the infiltrated precipitation emerges from seeps and springs along the tops of these interbeds where they are breached by the rugged topography of the Hill Country. Notable differences in hydraulic head result from these vertically staggered interbeds of relatively impermeable strata (Ashworth, 1983).

The upper member of the Glen Rose Limestone is divided for this report into five mappable intervals, A through E (youngest to oldest), as first applied by A.K. Clark (2003) to the Camp Bullis area of northern Bexar County (pl. 1). Characteristics of these intervals are summarized below:

Interval A (greater than 120 feet thick) has an abundance of caves-indicative of its generally well developed fracture, channel, and cavern porosity that in places provides appreciable permeability.

Interval B (120 to 150 feet thick) is similar to Interval A but with less cave development and permeability.
Interval C (18 to 26 feet thick), a partly to mostly dissolved zone of soluble carbonate rock, is characterized by breccia porosity, with collapse structures and boxwork permeability that typically intercept the downward percolation of ground water and divert it laterally.

Interval D (135 to 180 feet thick) generally has little porosity and permeability, but some local exceptions-most notably, the biostrome near the top of the interval-tend to have greater porosity and permeability.

Interval $\mathrm{E}$ ( 6 to 16 feet thick) is a partly to mostly dissolved sequence of evaporites similar to that in Interval C, with similar hydrogeologic properties and tendency to divert ground water laterally.

Faults in the Trinity aquifer of the Hill Country do not affect ground-water flow as much as they do in the Edwards aquifer of the Balcones fault zone (Maclay and Small, 1986; Barker and Ardis, 1996). Faults are much less common and have considerably less displacement north of the Balcones escarpment (fig. 2). Where faults occur in the study area, however, they can affect the rates of recharge and discharge as well as the patterns of ground-water flow - and, therefore, the vulnerability of the aquifer to contamination. Because barrier faults impede ground-water flow, they typically increase retention times and, therefore, the risk of ground-water contamination. Where faults have produced fractures that increase the permeability of the aquifer, they might increase the vulnerability of the aquifer to water-quality degradation.

Where caves or sinkholes affect local drainage patterns, they generally increase the vulnerability of the aquifer to ground-water contamination. Most of the increased vulnerability results from increased infiltration rates owing not only to the obvious enhancement they provide to the local permeability but also to the internal drainage associated with the closed depressions that typically result from the formation of these features. In some places, these features provide passageways for water to directly enter the Trinity aquifer.

Although the Trinity aquifer discharges to most Hill Country streams, parts of this aquifer are recharged by some reaches of some streams (Reeves and Lee, 1962). Cibolo Creek, which forms the northern boundary of the study area, crosses into the recharge zone of the Edwards aquifer and traverses the Balcones fault 
zone east of San Antonio. The upper part of the Cibolo Creek watershed includes a karstic reach characterized by caves and sinkholes. Although most reaches of Cibolo Creek are dry much of the time, they generally contain considerable runoff after heavy or prolonged rainstorms. Because much runoff in Cibolo Creek is diverted underground through sinkholes (Ashworth, 1983, p. 47), these sinkholes might contribute recharge to the Edwards aquifer.

\section{METHOD OF ASSESSING GROUND- WATER VULNERABILITY}

The present assessment of northern Bexar County's vulnerability to ground-water contamination was accomplished in four basic steps. First, information gleaned from the hydrogeologic literature and well records was combined with the recent results of field mapping (A.R. Clark, 2003) to compile a comprehensive hydrogeologic map of the study area. Second, existing methods of assessing ground-water vulnerability were reviewed and modified as necessary to satisfy the particular objectives of the present study. Third, the hydrogeologic units and other natural features believed to most affect northern Bexar County's vulnerability to ground-water contamination were identified and assigned vulnerability ratings on a feature-by-feature basis. These vulnerability ratings (associated with each feature) were then integrated into composite ratings and, finally, a vulnerability map of the entire study area. The existing methods, individual vulnerability ratings, and resulting vulnerability map of composite ratings are discussed in greater detail below.

Two existing methods of assessing conditions of ground-water contamination were considered before combining aspects of both to obtain the most appropriate approach for the present study. The first method considered originates from Title 30 of the Texas Administrative Code. Chapter 213 of this code mandates that geologic assessments be performed and development plans be approved before land plats are completed on the Edwards aquifer recharge zone (John Mauser, Texas Natural Resource Conservation Commission, written commun., 1995). To assist water planners, managers, regulators, and land developers in complying with the associated regulations, the Texas Natural Resource Conservation Commission (as of September 2002, the Texas Commission on Environmental Quality) in 1995 drafted a set of instructions to geologists making the required assessments. The current version of these instructions (Texas Natural Resource Conservation Commission, 2002) identifies specific hydrogeologic features (including stratigraphic, structural, and karstic characteristics) and anthropogenic conditions (for example, sewer lines and other man-made objects) in the study area to help evaluate the potential for contamination.

The second method considered by the present study is known as DRASTIC (Depth to water, [net] Recharge, Aquifer media, Soil media, Topography [slope], Impact of the vadose [unsaturated] zone media, and Conductivity [hydraulic] of the aquifer). DRASTIC was developed by the U.S. Environmental Protection Agency to evaluate, using existing information, the pollution potential of any hydrogeologic setting in the United States (Aller and others, 1987). According to Aller and others $(1987$, p. 1), "Pollution potential is a combination of hydrogeologic factors, anthropogenic influences and sources of contamination in any given area."

The procedures adapted by the present study to assess ground-water vulnerability are consistent with the decision by A.K. Clark (2000) to consider the effects of hydrogeologic units, faults, caves and (or) sinkholes, slopes, and soils. Data specific to each of these features were translated from the hydrogeologic literature or obtained through field observation. Using geographic informations system (GIS) technology, the relevant data were entered into vector-type digital datasets for display and analysis. These datasets were distinguished by point, line, or polygon attributes, depending on the spatial aspects of each feature (for example, faults were stored as line data; caves as point data; and soils as polygon data). After vulnerability ratings were related to each feature on the basis of discernible subcategories, the datasets were converted to a grid-based system of five data layers (fig. 3). GIS algorithms were then used to integrate the feature-based individual ratings into the composite ratings reflected in the vulnerability map (pl. 1) of the entire study area. Finally, using documentation software, metadata were developed to aid in the maintenance and future use of key data. The five categories of natural features that are represented in the present assessment of vulnerability are discussed under separate headings below.

\section{Hydrogeologic Units}

A hydrogeologic unit is defined as a mappable rock sequence with common geologic characteristics 
Composite vulnerability (plate 1)

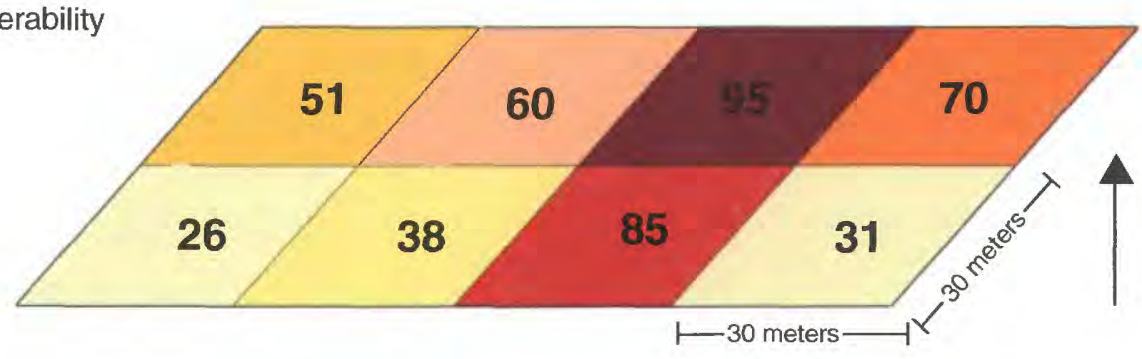

Hydrogeologic unit layer

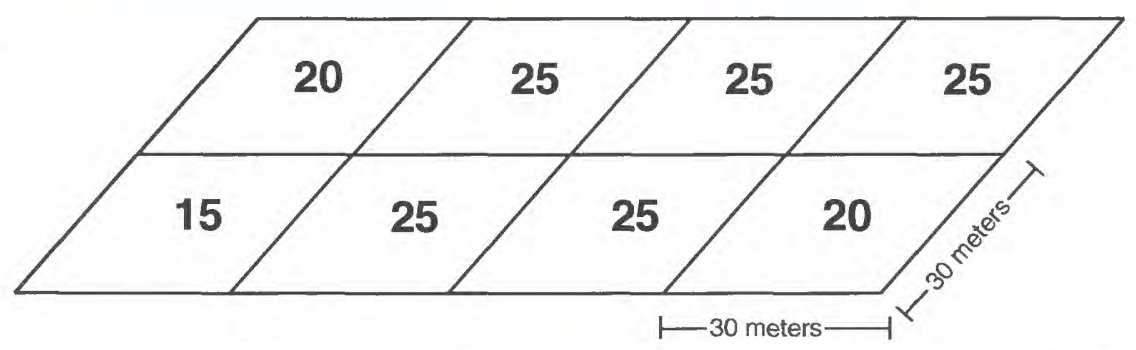

Fault layer

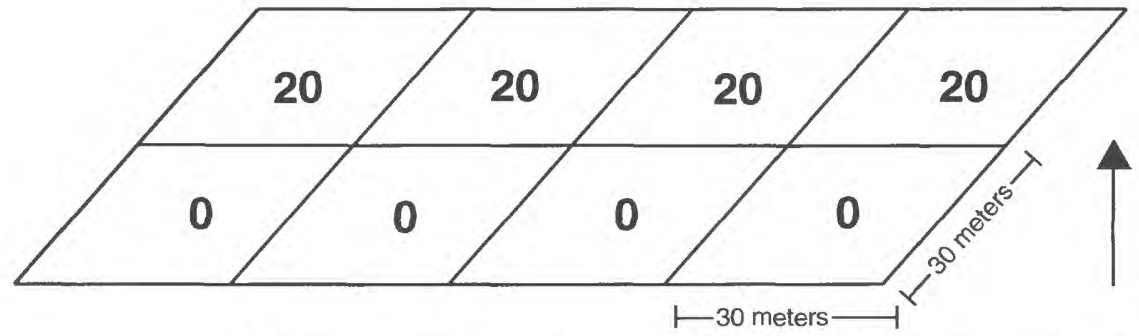

Cave or sinkhole layer

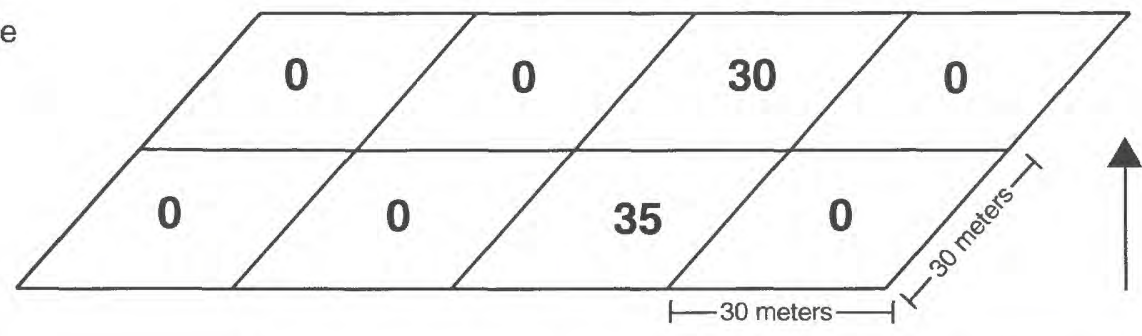

Slope layer

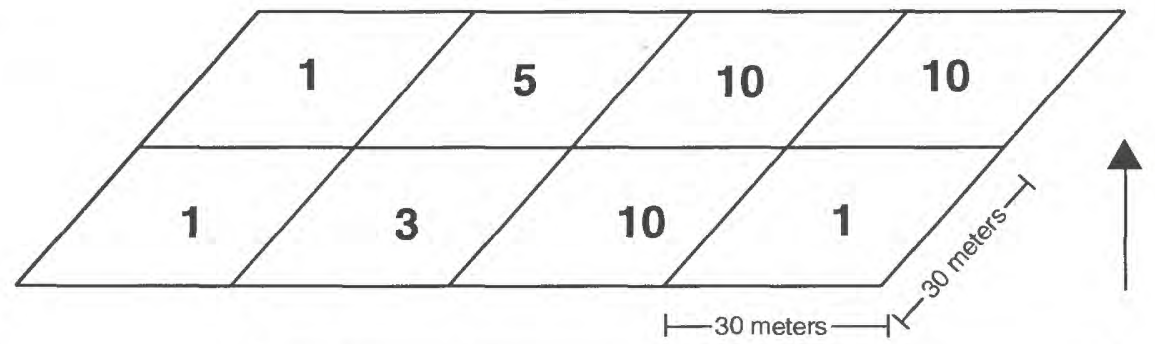

Soil layer

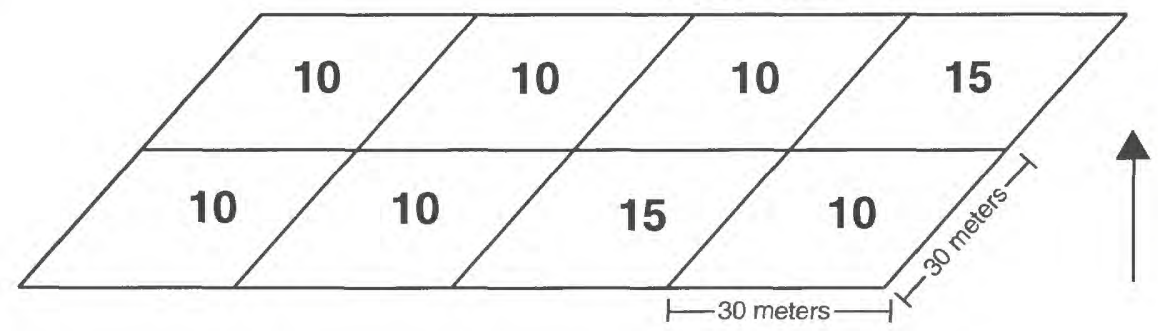

Figure 3. An example of how vulnerability ratings for the hydrogeologic units and other natural features relate to composite ratings (modified from A.K. Clark, 2000). 
and hydrologic properties and, as a consequence, common vulnerability to contamination by introduced pollutants (Aller and others, 1987). Because the effective porosity and permeability differs from one hydrogeologic unit to another, some provide more opportunity for pollutants to penetrate their upper surfaces and potentially contaminate underlying aquifers. Table 1 summarizes the geologic characteristics and hydrologic properties of the hydrogeologic subdivisions of the Edwards and Trinity Groups in northern Bexar County.

The hydrogeologic units in the study area were mapped on and digitized from 7.5-minute topographic maps. Field identification of the Kainer Formation and Glen Rose Limestone subdivisions were based on the identification of index fossils and on observable differences in lithology. Thicknesses of the evaporite beds in the upper member of the Glen Rose Limestone were determined on the basis of average thicknesses as inferred from well logs.

The hydrogeologic units were assigned vulnerability ratings (table 2 ) on the basis of previous hydrogeologic investigations (A.K. Clark, 2000) and more recent field observations (A.K. Clark, 2003). The most porous and permeable units, such as the dolomitic member of the Kainer Formation and intervals $\mathrm{C}$ and $\mathrm{E}$ (evaporite beds) of the upper member of the Glen Rose Limestone were assigned ratings of 25 . The least porous and permeable (clay-rich) units in the Glen Rose Limestone were assigned ratings of 15 .

Isolated outliers of the Edwards Group-for example, the hilltop remnants in the Hill Country (fig. 2) - were rated and included in the vulnerability map owing to an apparent hydraulic connection to the underlying Trinity aquifer. Where such remnants cap hills or ridges that are otherwise underlain by the Trinity Group, the Trinity aquifer might be vulnerable to the downward migration of contaminated ground water.

\section{Faults}

Faults were mapped in the field from the observation of abrupt lithologic and (or) stratigraphic dissimilarities and at least one of the following: fault scarp, fault breccia, long linear travertine or sparry calcite deposit, or steeply dipping strata thought to represent a fault-bend (drape) fold. The extent of many faults, or their extension into mapped areas, was inferred from lineaments visible on the land surface or in aerial photographs. All recognized faults were plotted on
Table 2. Composite vulnerability ratings for the hydrogeologic units and other natural features in the study area of northern Bexar County, Texas

[Modified from A.K. Clark (2000)]

\begin{tabular}{|c|c|c|}
\hline $\begin{array}{l}\text { Natural } \\
\text { feature }\end{array}$ & $\begin{array}{l}\text { Subdivision of hydrogeologic } \\
\text { unit or other natural feature }\end{array}$ & Rating \\
\hline \multirow{11}{*}{$\begin{array}{l}\text { Hydrogeo- } \\
\text { logic unit }\end{array}$} & Kainer Formation: & \\
\hline & Dolomitic member & 25 \\
\hline & Basal nodular member & 15 \\
\hline & Glen Rose Limestone: & \\
\hline & Upper member & \\
\hline & Interval A & 15 \\
\hline & Interval B & 15 \\
\hline & Interval C & 25 \\
\hline & Interval D & 15 \\
\hline & Interval E & 25 \\
\hline & Lower member & 20 \\
\hline \multirow{2}{*}{ Fault } & Fault present & 20 \\
\hline & No fault present & 0 \\
\hline \multirow{4}{*}{$\begin{array}{l}\text { Cave or } \\
\quad \text { sinkhole }\end{array}$} & One cave present & 30 \\
\hline & $\begin{array}{l}\text { More than one cave present } \\
\text { (cave zone) }\end{array}$ & 35 \\
\hline & $\begin{array}{l}\text { Sinkhole and closed depres- } \\
\text { sions present }\end{array}$ & 20 \\
\hline & No cave or sinkhole present & 0 \\
\hline \multirow{5}{*}{$\begin{array}{l}\text { Slope (with } \\
\text { soil) }\end{array}$} & Greater than 18 percent & 1 \\
\hline & Greater than 12 to 18 percent & 3 \\
\hline & Greater than 6 to 12 percent & 5 \\
\hline & Greater than 2 to 6 percent & 9 \\
\hline & Less than or equal to 2 percent & 10 \\
\hline \multirow{3}{*}{ Soil } & No soil present & 20 \\
\hline & Moderately permeable & 15 \\
\hline & Slightly permeable & 10 \\
\hline
\end{tabular}

7.5-minute topographic maps, from which they were later digitized into a vector dataset.

Faults are not as numerous or as well developed in the Glen Rose Limestone as they are in the Edwards Group and are less apt to enhance infiltration from land surface owing to their occurrence in less permeable strata, generally smaller vertical displacement, and less tendency to be associated with shattered zones. The density of fractures tends to increase near faults, providing the potential for additional ground-water flowpaths.

Because the dominant network of southwestto-northeast-trending faults in the Balcones fault zone 
(fig. 1) tends to enhance northeastern flow and impede southeastern flow in the Edwards aquifer (A.K. Clark, 2000), faults might potentially control the direction and velocity of contaminant transport in parts of the study area. In areas near Cibolo Creek, where the combination of faulting and karstification has caused unusually permeable zones within the Glen Rose Limestone to resemble subsurface conduits, downgradient areas of the Edwards aquifer might be inherently more susceptible to a direct connection with potentially contaminated runoff from the Glen Rose Limestone.

For the present study, faults were assumed to increase the vulnerability of ground water to contamination owing to their known capacity to enhance recharge opportunities. Accordingly, all mapped faults were assigned a vulnerability rating of 20 . This rating is consistent with the updated instructions to geologists assessing ground-water vulnerability in the recharge and transition zones of the Edwards aquifer (Texas Natural Resource Conservation Commission, 2002). Areas of no recognized faults were assigned a zero rating.

\section{Caves and (or) Sinkholes}

Bates and Jackson (1984) define a cave as a natural cavity, recess, chamber, or series of chambers and galleries beneath the surface of the earth, large enough for a person to enter. To qualify as a cave for the purposes of this report, the chamber must be large enough to accept an average-sized adult. Presently, 62 caves are located within the study area of northern Bexar County.

Most caves (or caverns) are formed by the dissolution of limestone, caused typically by meteoric or undersaturated ground water. Caves are primary contributors to the threat of contamination not only because of the unusually large volumes of water they can admit, but also because they commonly are point sources of contamination with the capacity to convey pollutants directly to area aquifers.

Sinkholes are closed, roughly circular depressions with subterranean drainage systems in karstic areas. Sinkholes are formed by the massive dissolution of carbonate minerals at or near land surface and (or) by the collapse of underlying caves. Sinkholes are commonly funnel-shaped, large-scale features with size measured in tens or hundreds of feet. In some cases a swallow hole, or swallet, might be present at the bottom of the sinkhole where surface water can disappear into underground fractures or solution cavities.
Potential cave and sinkhole locations were compiled for the study area from reports by private citizens, non-government organizations, and government agencies. Most caves and sinkholes were field-checked and pinpointed on 7.5-minute topographic maps with the aid of a global positioning system (GPS) device. Other locations-such as those identified by caving organizations-were field-checked where possible. All confirmed caves and sinkholes were digitized into the GIS database as points.

These point features were then consolidated within buffered areas which, in turn, were used to establish what are herein called "cave zones." Cave zones were established from criteria selected in collaboration with Dr. George Veni, a local karst hydrogeologist and 2002 Texas Speleological Survey (TSS) president. As delineated, the cave zones depict irregular, polygonal patterns with geologic boundaries and (or) lithologic horizons where more than one cave exists or is likely to exist. Information regarding the location of caves was provided provisionally by the TSS with the understanding that cave locations would not appear as points on the final vulnerability map. This was believed necessary to protect not only the exact location of caves but also the rights of property owners.

Areas with no caves or sinkholes were assigned vulnerability ratings of zero. Sinkholes (including closed depressions) were rated as 20 . Whereas a single cave was rated as 30 , a cave zone (more than one cave) was rated 35. In addition to being assigned on the basis of advice from local karst specialists, these ratings are consistent with the current instructions to geologists making geologic assessments of the Edwards aquifer recharge and transition zones (Texas Natural Resource Conservation Commission, 2002).

The presently recognized locations and effects of caves and sinkholes in the study area depend most importantly on the observations of cave explorers and their efforts to map specific caves. The knowledge of cave and sinkhole locations should improve as access to uncharted areas is obtained and more caves are discovered and mapped. The appropriateness of cave zone analysis, likewise, should improve as the understanding of this concept evolves.

\section{Slopes}

The land-surface altitudes for determining slope in the study area were adopted from U.S. Geological Survey 7.5-minute digital elevation models (DEMs). 
DEMs are datasets that contain three-dimensional (x,y, and z) location and elevation data for each cell, or 30by 30 -meter (900-square meter) subdivision of the study area. The $\mathrm{z}$ direction (also measured in meters) represents the altitude of land surface at the center of each cell. The percent slope (calculated as the percent change in altitude over a specific map distance) was used to assign vulnerability ratings to all cells in the slope layer (GIS dataset).

The rating system used is based on the modification by A.K. Clark (2000) of the DRASTIC ratings for slope (Aller and others, 1987). Slopes greater than 18 percent were rated as 1 ; slopes greater than 12 and as much as 18 percent were rated as 3 ; slopes greater than 6 and as much as 12 percent were rated as 5; slopes greater than 2 and as much as 6 percent were rated as 9; and slopes less than or equal to 2 percent were rated as 10. The assigned ratings are based on the assumption that 0 - to 2-percent slopes provide the greatest opportunity for pollutants to infiltrate the surface because neither a pollutant nor precipitation is likely to exit the area as direct (surface-water) runoff. On the opposite end of the scale are slopes of greater than 18 percent-providing a much larger likelihood of direct runoff and a much smaller opportunity for infiltration and, therefore, a relatively small risk of ground-water contamination.

As higher resolution DEMs become available, the slope dataset will improve accordingly. The resulting refinement in the slope data should provide more appropriate assessments of vulnerability, especially in areas where the effect of slope is not diminished by the effects of other natural features.

\section{Soils}

Soils can have an appreciable effect on whether or not, or how quickly, a fluid will infiltrate the land surface and perhaps percolate to the water table. Because different soils have different characteristics of permeability - and hence, different infiltration capacities - they present a variation of contamination risks. Soils can reduce the potential for ground-water contamination by trapping pollutants within its matrix and, thus, impede the further migration of a potential contaminant in the subsurface. The presence of fine-textured materials, such as silt or clay, can likewise decrease soil permeability and the threat of contamination.

The soil dataset used for the present study was adapted from a soil survey by the Natural Resources
Conservation Service. This dataset provides the areal distribution of soils, by name and slope, in northern Bexar County. The survey results include qualitative descriptors of the "degree of limitation for use as a sewage-disposal field" (Natural Resources Conservation Service, 1995, table 4) and relative permeability for each soil. With a cell resolution of 30 by 30 meters, the present soil dataset contains vulnerability ratings (table 2) assigned on the basis of the qualitative descriptors and relative permeability categories suggested by the Natural Resources Conservation Service (1995).

Cells with land-surface slopes of less than 30 percent were assigned ratings of 15 or 10 , depending on the relative permeability of the soil type. For example, Tarrant association soils-which cover 27 percent of the study area and are classified as moderately permeablewere assigned a vulnerability rating of 15 . Krum complex and Patrick soils-which cover 12 and 2 percent of the study area, respectively, and are classified as slightly permeable-were assigned a rating of 10 . Other land areas-which include ponds, pits, and quarries and account for 0.12 percent of the area-were assigned a vulnerability rating of 20 on the basis of Taylor and others (1966).

Taylor and others (1966, p. 103) additionally indicate that, owing to erosion, steep areas characteristically do not support appreciable thicknesses of soil. Consequently, steep areas (slopes of 30 percent or greater, as interpreted for northern Bexar County) were assigned a vulnerability rating of 20 on the assumption that-with little or no soil to impede infiltration-such areas are relatively vulnerable to contamination.

Soils have minimal effect on the variability of ground-water vulnerability in the study area because the outcrop of the Glen Rose Limestone typically is not conducive to thick accumulations of soil. Where soils are present, they tend to be thin and uniform in composition-not the kind of thick, loamy soils with relatively high capacities for buffering an underlying aquifer from contamination.

\section{GROUND-WATER VULNERABILITY MAP}

Plate 1 shows the spatial distribution of groundwater vulnerability to contamination in the study area as composited from the individual vulnerability ratings assigned to the selected natural features (hydrogeologic units, faults, caves or sinkholes, slopes, and soils). Vulnerability is indicated by a series of discrete ranges from least vulnerable (shades of yellow) to intermediately 
vulnerable (shades of orange) to most vulnerable (shades of red). The possible composite ratings range from 26 to 110 ; actual ratings range from 26 to 104 . Least-vulnerable areas (composite ratings of 26 to 55) account for about 92 percent of the study area; intermediately vulnerable areas (composite ratings of 56 to 75) account for about 7 percent; and most-vulnerable areas (composite ratings of 76 to 104) account for about 1 percent. The distribution of the most vulnerable areas trends from southwest to northeast, roughly parallel to the Balcones fault zone.

Table 2 and figure 4 show that if an area represented by a 30 - by 30 -meter cell on the vulnerability map does not contain a fault, sinkhole, or cave, then the composite vulnerability rating for that cell must fall between 26 and 55 (26 equals 15 for hydrogeologic unit [ignoring a few, minor outcrops of the dolomitic member] plus 1 for slope plus 10 for soil; 55 equals 25 for hydrogeologic unit plus 10 for slope plus 20 for soil). If a cell contains a fault (rated as 20) or sinkhole (20) or cave (30) or cave zone (35), then the composite rating for that cell would range from 46 (minimum of 26 plus 20 ) to 90 (maximum of 55 plus 35 ). Finally, the composite rating for a cell containing both a fault and one or more caves would range from 76 to 110 .

Figure 4 further shows that, in general, areas with no fault, cave, or sinkhole are the least vulnerable; areas with either a fault or sinkhole or one or more caves are relatively more vulnerable; and areas with both a fault and one or more caves are the most vulnerable. The relation between the presence of these features and increasing vulnerability is not absolute, however, as indicated by the overlap in the three ranges of composite ratings representing feature combinations overlain on the cumulative relative frequency distribution.

\section{CONSIDERATIONS AND LIMITATIONS}

The method used in this study to assess groundwater vulnerability to contamination is a subjective rating method known as an index method. The index method has been a popular approach for assessment of ground-water vulnerability because it is straightforward computationally and uses commonly available data. However, the method has three primary shortcomings to producing a scientifically defensible assessment (Focazio and others, 2002): (1) The ratings for individual factors, although relatively consistent and logical and based on best engineering judgment, are subjectively selected; (2) the compositing of the factors is totally subjective and not a process-based method - that is, the physics of the hydrologic system are not incorporated; and (3) the uncertainty or sensitivity of the computed results cannot be determined.

The results provided herein are relevant to the scales of the USGS 7.5-minute DEMS and the 30- by 30 -meter cells used to assess vulnerability over the 180square-mile study area. The results (pl. 1) are likely to be less appropriate, therefore, for relatively small areas of less than about 10,000 square feet. Site-specific investigation is recommended to fill the gaps resulting from the shortcomings inherent in the scale of the present study.

Many assumptions went into the determination of the vulnerability ratings (table 2 ) assigned to the hydrogeologic units (table 1) and other natural features believed to most affect the vulnerability of ground water to contamination in the study area (pl. 1). Where any one or a combination of these ratings is flawed, the composite vulnerability assessment (pl. 1) is likely to be biased, accordingly. Owing to the subjectivity of the vulnerability-rating process, the relatively large scale of the present analysis, and the resulting potential for biased results, any photographic or digital enlargement of the information on plate 1 is not recommended.

It is unlikely that all faults, caves, and sinkholes in the study area have been accounted for, or that the effects of soil, slope, and hydrogeologic unit have been completely incorporated. Therefore, it should not be assumed that all features affecting vulnerability are entirely or accurately incorporated in the composite vulnerability patterns depicted on plate 1 . Many features that are known to affect vulnerability are likely unmapped because their surface expressions are obscured by soil, colluvium, and (or) vegetation. For example, yet-undetected faults might include those with no noticeable disruption of the present topography, particularly if the rocks on both sides of such faults have experienced similar weathering effects or if the rates of displacement have been no different than the rates of erosion. Similarly, the portals of yet-unrecognized caves and sinkholes are possibly covered by trees, brush, and (or) associated debris.

Considering that the Edwards aquifer is recharged by runoff from the outcrop of the Trinity aquifer might indicate an inverse relation between the vulnerability of ground water to contamination in the Glen Rose Limestone and a resulting vulnerability in the downgradient Edwards aquifer. In other words, areas of Glen Rose Limestone that are most vulnerable to contamination 


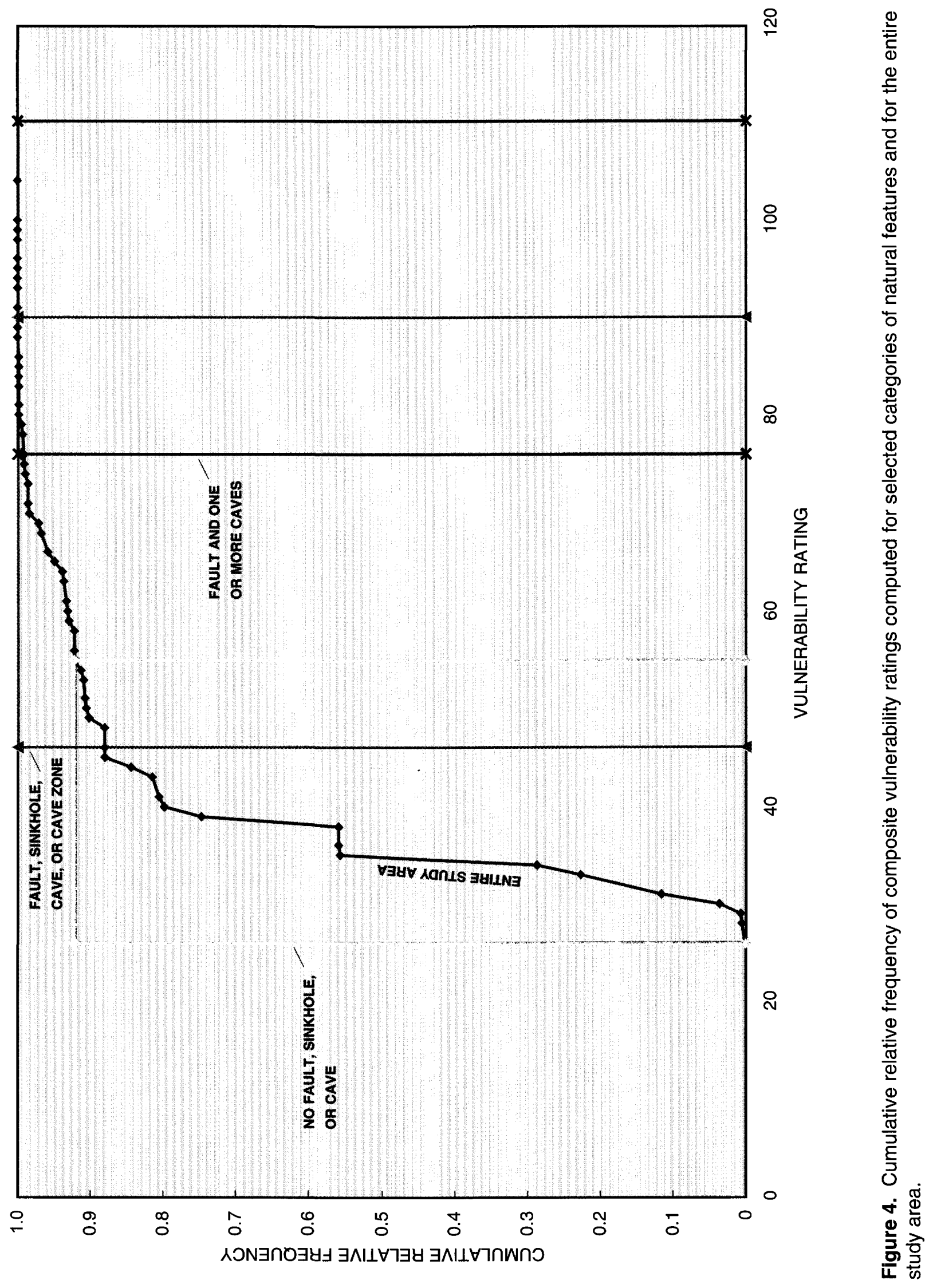


might offer the greatest protection against that contamination directly affecting the Edwards aquifer. By the same reasoning, the relatively impermeable upgradient areas (of relatively little local vulnerability) might pose the greatest threat to the pervious recharge zone of the downgradient Edwards aquifer. Although such an inverse relation might seem intuitive, the exact nature of such a relation has not been studied nor is it known whether or not-or to what extent-it might apply over the long term.

Although plate 1 is available now as another tool for water managers and regulators making land-use decisions, the vulnerability map will change as additional observations are made and more accurate analyses are completed. Less subjective, less biased delineations of vulnerability will evolve as additional data on hydrogeologic units, faults, caves, sinkholes, slopes, and soils are collected, analyzed, and factored into future analyses.

Plate 1 provides only one of the many considerations that should contribute toward any assessment of the risks and effects of potential ground-water contamination in northern Bexar County. No part of the vulnerability assessment offered herein is intended to preclude or minimize the importance of detailed, onsite inspections by qualified hydrogeologists (Texas Natural Resource Conservation Commission, 2002).

\section{SUMMARY}

The ground-water hydrology of the 180-squaremile study area in northern Bexar County is controlled largely by the Trinity aquifer, a subsurface reservoir composed of Lower Cretaceous carbonate rocks. Discharge from the Trinity aquifer recharges the downgradient, hydraulically connected Edwards aquifer-one of the most permeable and productive aquifers in the Nation and the sole source of water for more than a million people in south-central Texas. The unconfined, karstic nature of the Edwards aquifer makes it particularly vulnerable to contamination resulting from urbanization that is spreading rapidly northward across the "environmentally sensitive" recharge zone of the Edwards aquifer and its "catchment area" on the outcrop of the upgradient, comparatively less permeable Trinity aquifer.

A better understanding of the Trinity aquifer is needed to properly evaluate water-management decisions affecting the quality of water in the Trinity as well as in the Edwards aquifer. In addition to depending on the distribution and characteristics of the study area's hydrogeologic units, the vulnerability of ground water to contamination depends on the presence or absence of faults, caves, and sinkholes and on the slopes and soils on the surface and in the shallow subcrop of the Trinity aquifer. The spatial distribution of the resulting vulnerability varies with the composite (net) effect of these natural features. The present study was undertaken in cooperation with the San Antonio Water System (SAWS) to assess the vulnerability of ground water to contamination in northern Bexar County.

The upper two (of three) water-yielding zones in the Trinity aquifer crop out over about 90 percent of the study area. The upper zone is composed of the upper member of the Glen Rose Limestone and the uppermost part of the middle zone is composed of the lower member of the Glen Rose Limestone. Whereas the upper member is characteristically thin-bedded and composed mostly of alternating beds of relatively resistant limestone and comparatively soft marl, the lower member typically is composed of relatively massive, fossiliferous limestone. The Glen Rose Limestone is uncharacteristically permeable in northern Bexar County, where caves and sinkholes have developed in elevated areas north of the Balcones fault zone.

For purposes of the present study, the upper member of the Glen Rose Limestone is divided into five mappable intervals, A through $\mathrm{E}$ (youngest to oldest):

Interval A (greater than 120 feet thick) has an abundance of caves-indicative of its generally well developed fracture, channel, and cavern porosity.

Interval B (120 to 150 feet thick) is similar to Interval A, but with less cave development and permeability.

Interval C (18 to 26 feet thick), a partly to mostly dissolved zone of soluble carbonate rock with collapse structures and boxwork permeability.

Interval D (135 to 180 feet thick) generally has little porosity and permeability, but some local exceptions.

Interval $\mathrm{E}$ ( 6 to 16 feet thick) is a partly to mostly dissolved sequence of evaporites similar to that in Interval $\mathrm{C}$.

Although there are fewer and less pronounced faults in the Trinity aquifer than in the Edwards aquifer, where faults occur they can affect the rates of recharge 
and discharge as well as the patterns of ground-water flow-and, therefore, the vulnerability to contamination. Barrier faults typically increase retention times and, therefore, the risk of ground-water contamination. Where faults and associated fractures increase the local permeability, they likewise can increase the risk of water-quality degradation.

Where caves or sinkholes affect local drainage patterns, they generally increase the vulnerability to ground-water contamination. In some places these features provide passageways for water to directly enter the Trinity aquifer. Most of the vulnerability resulting from caves and sinkholes is caused by increased infiltration rates owing to the enhancement of the local permeability and the internal drainage associated with the closed depressions that typically characterize such features.

The slope of land surface can affect the vulnerability of the underlying aquifer to contamination by controlling where and how long a potential contaminant remains on the surface. Disregarding the exception of steep slopes - which are assumed to have no soil cover-the greater the slope, the less the risk of groundwater contamination.

Because most soils in the study area are uniformly thin, they have only minimal effect on the vulnerability of ground water to contamination.

Because Tarrant association soils are "moderately permeable," they are assumed least effective in reducing the vulnerability to ground-water contamination. Areas underlying the "slightly permeable" Krum complex and Patrick soils are assumed somewhat less vulnerable to contamination.

The vulnerability assessment provided herein was accomplished in four basic steps. First, information from the literature and well records was combined with the results of recent field mapping to compile a hydrogeologic map of the study area. Second, existing methods of assessing ground-water vulnerability were modified to best satisfy the present objectives. Third, the hydrogeologic units and other natural features believed to most affect the vulnerability of ground water to contamination were rated on a scale of 0 to 35 . Fourth, vulnerability ratings assigned to each feature were incorporated into a grid-based, multilayer (GIS) database that allowed the integration of applicable data into a ground-water vulnerability map of the entire study area (where composite vulnerability ratings range from 26 through 104).

The relatively less vulnerable areas-those with no faults, sinkholes, or caves-have composite vulnera- bility ratings of 55 or less. Areas of relatively intermediate vulnerability - those with either a fault or sinkhole or cave or cave zone (more than one cave)-have composite ratings ranging from 46 to 90 . The relatively more vulnerable areas - those with both a fault and one or more caves-have ratings greater than 75 .

The relatively less vulnerable areas - those with no faults, sinkholes, or caves-occupy about 92 percent of the study area. The distribution of the most vulnerable areas-which trend from southwest to northeast, roughly parallel to the Balcones fault zone-occur mainly where faults intersect caves.

This report offers another tool for water managers and regulators who must make decisions regarding the risks and effects of potential ground-water contamination in the study area of northern Bexar County. The understanding of the vulnerability of ground water to contamination in the area is evolving as additional data on hydrogeologic units, faults, caves, sinkholes, slopes, and soils are collected and analyzed. No part of the vulnerability assessment offered herein is intended to preclude or minimize the importance of detailed, onsite inspections by qualified hydrogeologists.

\section{REFERENCES}

Aller, Linda, Bennett, Truman, Leer, J.H., Petty, R.J., and Hackett, Glenn, 1987, DRASTIC-A standardized system for evaluating ground water pollution potential using hydrogeologic settings: U.S. Environmental Protection Agency, EPA/600/2-87/035, 455 p.

Ashworth, J.B., 1983, Ground-water availability of the Lower Cretaceous Formations in the Hill Country of southcentral Texas: Texas Department of Water Resources Report 273, $173 \mathrm{p}$.

Barker, R.A., and Ardis, A.F., 1996, Hydrogeologic framework of the Edwards-Trinity aquifer system, westcentral Texas: U.S. Geological Survey Professional Paper 1421-B, $61 \mathrm{p}$.

Bates, R.L., and Jackson, J.A., eds., 1984, Dictionary of geological terms ( $3 \mathrm{~d}$ ed.): American Geological Institute, $571 \mathrm{p}$.

Choquette, P.W., and Pray, L.C., 1970, Geologic nomenclature and classification of porosity in sedimentary carbonates: American Association of Petroleum Geologists Bulletin, v. 54, no. 2, p. 207-250.

Clark, A.K., 2000, Vulnerability of ground water to contamination, Edwards aquifer recharge zone, Bexar County, Texas, 1998: U.S. Geological Survey Water-Resources Investigations Report 00-4149, 9 p., 1 pl.

2003 , Geologic framework and hydrogeologic features of the Glen Rose Limestone, Camp Bullis Training 
Site, Bexar County, Texas: U.S. Geological Survey Water-Resources Investigations Report 03-4081, 9 p., $1 \mathrm{pl}$.

Clark, A.R., 2003, Geologic framework, hydrogeologic characteristics and vulnerability assessment of the Glen rose Limestone in the catchment area of the Edwards aquifer, Bexar County, Texas: University of Texas at San Antonio, M.S. thesis, $57 \mathrm{p}$.

Dunham, R.J., 1962, Classification of carbonate rocks according to depositional texture, in Classification of Carbonate Rocks Symposium: American Association of Petroleum Geologists Memoir 1, p. 108-121.

Focazio, M.J., Reilly, T.E., Rupert M.G., and Helsel, D.R., 2002 , Assessing ground-water vulnerability to contamination-Providing scientifically defensible information for decision makers: U.S. Geological Survey Circular $1224,33 \mathrm{p}$.

Lanning-Rush, Jennifer, 2000, Regional equations for estimating mean annual and mean seasonal runoff for natural basins in Texas, base period 1961-90: U.S. Geological Survey Water-Resources Investigations Report $00-4064,27 \mathrm{p}$.

Maclay, R.W., and Small, T.A., 1986, Carbonate geology and hydrology of the Edwards aquifer in the San Antonio area, Texas: Texas Water Development Board Report $296,90 \mathrm{p}$.

National Research Council, 1993, Ground water vulnerability assessment-Predicting relative contamination potential under conditions of uncertainty: Washington, D.C., National Academy Press, 224 p.

Natural Resources Conservation Service, 1995, Soil survey geographic (SSURGO) database for Bexar County, Texas: U.S. Department of Agriculture.

Owenby, J.R., and Ezell, D.S., 1992, Monthly station normals of temperature, precipitation, and heating and cooling degree days, 1961-90, Texas: Asheville, N.C., National
Oceanic and Atmospheric Administration, National Climatic Data Center, Climatography of the United States, no. $81,65 \mathrm{p}$.

Reeves, R.D., and Lee, F.C., 1962, Ground-water geology of Bandera County, Texas: Texas Water Commission Bulletin 6210, $73 \mathrm{p}$.

Rose, P.R., 1972, Edwards Group, surface and subsurface, central Texas: Austin, Tex., University of Texas, Bureau of Economic Geology Report of Investigations 74, $198 \mathrm{p}$.

Stein, W.G., and Ozuna, G.B., 1995, Geologic framework and hydrogeologic characteristics of the Edwards aquifer recharge zone, Bexar County, Texas: U.S. Geological Survey Water-Resources Investigations Report 95-4030, 8 p., 1 pl.

Taylor, F.B., Hailey, R.B., and Richmond, D.L., 1966, Soil survey of Bexar County, Texas: U.S. Department of Agriculture, Soil Conservation Service, series 1962, no. $12,126 \mathrm{p}$.

Texas Natural Resource Conservation Commission, 1995, Instructions to geologists for geologic assessments on the Edwards aquifer recharge/transition zones: Austin, Tex., 9 p. 2002, Instructions to geologists for geologic assessments on the Edwards aquifer recharge/transition zones (revised): Austin, Tex., $34 \mathrm{p}$.

U.S. Census Bureau, 2002, State and county quickfacts: Accessed October 1, 2002, at URL http://quickfacts.census.gov/qfd/states/48/48029.html van der Leeden, Frits, Troise, F.L., and Todd, D.K., 1990, The water encyclopedia: Chelsea, Mich., Lewis Publishers, Inc., p. 808.

Veni, George, 1994, Geomorphology, hydrology, geochemistry, and evolution of the karstic Lower Glen Rose aquifer, south-central Texas: Pennsylvania State University, Ph.D. dissertation, $712 \mathrm{p}$. 